\title{
High-resolution ice cores from US ITASE (West Antarctica): development and validation of chronologies and determination of precision and accuracy
}

\author{
Eric J. STEIG, ${ }^{1}$ Paul A. MAYEWSKI, ${ }^{2}$ Daniel A. DIXON, ${ }^{2}$ Susan D. KASPARI, ${ }^{2}$ \\ Markus M. FREY, ${ }^{3}$ David P. SCHNEIDER, ${ }^{1}$ Steven A. ARCONE, ${ }^{3}$ \\ Gordon S. HAMILTON, ${ }^{2}$ V. Blue SPIKES, ${ }^{2}$ Mary ALBERT, ${ }^{3}$ Deb MEESE, ${ }^{3}$
} Anthony J. GOW, ${ }^{3}$ Christopher A. SHUMAN, ${ }^{4}$ James W.C. WHITE, ${ }^{5}$ Sharon SNEED, ${ }^{2}$ Joseph FLAHERTY, ${ }^{1}$ Mark WUMKES ${ }^{7}$

\author{
${ }^{1}$ Department of Earth and Space Sciences, Box 351310, University of Washington, Seattle, WA 98195-1310, USA \\ E-mail: steig@ess.washington.edu \\ ${ }^{2}$ Climate Change Institute, University of Maine, 303 Bryand Global Sciences Center, Orono, ME 04469-5790, USA \\ ${ }^{3}$ Department of Hydrology and Water Resources, PO Box 210011, The University of Arizona, Tucson, AZ 85271-0011, USA \\ ${ }^{4}$ US Army Cold Regions Research and Engineering Laboratory, 72 Lyme Road, Hanover, NH 03755-1290, USA \\ ${ }^{5}$ NASA Goddard Space Flight Center, Code 971, Greenbelt, MD 20771, USA \\ ${ }^{6}$ Institute of Arctic and Alpine Research, University of Colorado, Boulder, CO 80309-0450, USA \\ ${ }^{7}$ Glacier Data, 750 Spudwood Road, Fairbanks, AK 99712, USA
}

\begin{abstract}
Shallow ice cores were obtained from widely distributed sites across the West Antarctic ice sheet, as part of the United States portion of the International Trans-Antarctic Scientific Expedition (US ITASE) program. The US ITASE cores have been dated by annual-layer counting, primarily through the identification of summer peaks in non-sea-salt sulfate $\left(\mathrm{nsSO}_{4}{ }^{2-}\right.$ ) concentration. Absolute dating accuracy of better than 2 years and relative dating accuracy better than 1 year is demonstrated by the identification of multiple volcanic marker horizons in each of the cores, Tambora, Indonesia (1815), being the most prominent. Independent validation is provided by the tracing of isochronal layers from site to site using high-frequency ice-penetrating radar observations, and by the timing of mid-winter warming events in stable-isotope ratios, which demonstrate significantly better than $\mathbf{1}$ year accuracy in the last 20 years. Dating precision to $\pm \mathbf{1}$ month is demonstrated by the occurrence of summer nitrate peaks and stable-isotope ratios in phase with nssSO ${ }_{4}{ }^{2-}$, and winter-time sea-salt peaks out of phase, with phase variation of $<1$ month. Dating precision and accuracy are uniform with depth, for at least the last 100 years.
\end{abstract}

\section{INTRODUCTION}

The International Trans-Antarctic Scientific Expedition (ITASE) program is an international effort to improve our spatial picture of the Antarctic ice sheet. ITASE places emphasis on the surface and near-surface characteristics of the ice sheet, complemented by deep ice radar profiling and atmospheric sampling at altitudes upwards of $20 \mathrm{~km}$. The first phase of the United States' effort has focused on the West Antarctic ice sheet (WAIS), and has completed four field seasons comprising oversnow traverses that included ice coring, atmospheric sampling, surface horizontal and vertical velocity measurements, and radar observations of near-surface stratigraphy, ice-sheet internal layering and bed topography. The traverses covered a total distance of $>5000 \mathrm{~km}$ and comprise an unprecedented sampling of the Antarctic ice sheet that, when combined with data from other ITASE projects, will result in a comprehensive spatial and temporal map of Antarctic climate, atmospheric chemistry and ice-sheet surface mass balance.

As part of US ITASE, ice cores were obtained from 23 sites across the WAIS, between the Antarctic Peninsula, South Pole and the Ross Sea and Amundsen Sea ice drainages. At 21 of these sites, cores reaching to depths between $\sim 50$ and $\sim 300 \mathrm{~m}$ were obtained, providing continuous records of snow chemistry covering at most sites at least 200 years, a benchmark time frame in the original ITASE implementation plan (Mayewski and Goodwin, 1996). These cores greatly expand the inventory, and widen the spatial coverage, of ice-core records available from earlier projects in West Antarctica, which include the long ice cores at Byrd (Johnsen and others, 1972) and Siple Dome (Taylor and others, 2004a), and shorter records from Siple Station and Dyer Plateau (Mosley-Thompson and others, 1990; Thompson and others, 1994) and in the Ross Ice drainage area (Kreutz and others, 2000a).

Ice-core records of past snow properties and near-surface atmospheric chemistry are widely used as proxy records of past climate conditions and as constraints for ice-sheet surface mass balance and ice deformation studies. The importance of obtaining multiple ice cores is that a single ice core, like a single weather station, will be representative only at some local or regional spatial scale, depending on the timescale of interest. This is particularly true in West Antarctica, because the spatial coherence of interannual climate variability is relatively small, and ice-sheet topography is sufficiently complex that there may also be significant microclimatic effects. Results from recent deep coring projects suggest that on longer timescales as well, significant climate changes appearing in one location in 


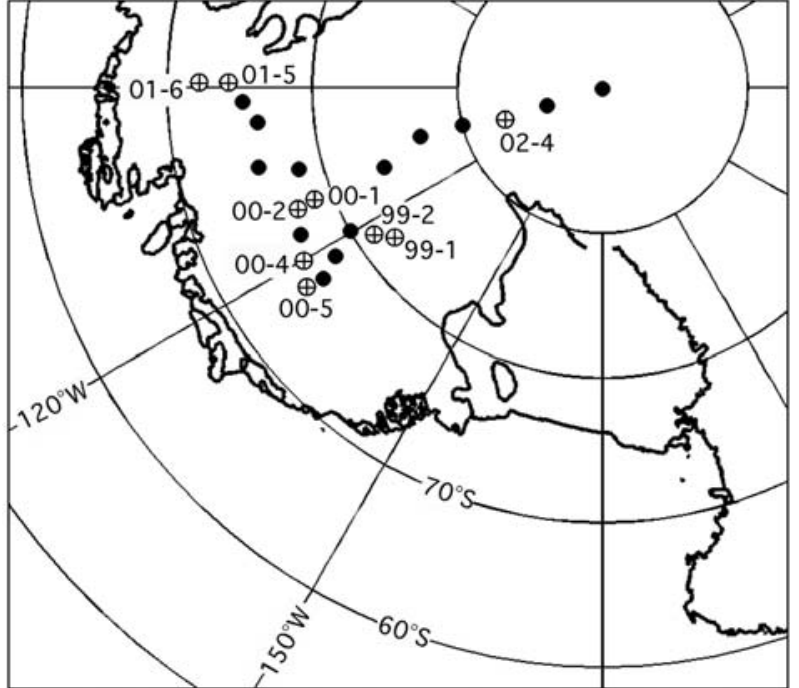

Fig. 1. Map of West Antarctica showing the location of US ITASE cores collected between 1999 and 2003. Locations specifically discussed in the text are named and shown by white circles with crosses.

West Antarctica may not necessarily be felt at another (e.g. Siple Dome vs Byrd; see Taylor and others, 2004a). In contrast, the East Antarctic ice sheet appears to be quite uniform on both short (Schneider and Steig, 2002; Schneider and others, 2004) and long timescales (Jouzel and others, 2001; Watanabe and others, 2003).

The use of multiple ice cores and the measurement of multiple parameters can provide complementary information about the atmospheric and surface conditions that are being sampled. Consistently accurate and precise dating of ice cores is critical to the success of this approach. Placing Antarctica in the context of global climate variability requires ice cores that can be rigorously calibrated against direct meteorological observations on the same timescales. In this paper, we discuss the methods used for developing depth vs age relationships for the USITASE cores, and we quantify the accuracy and precision of the resulting chronologies through several independent methods. Application of the resulting, highly resolved records to climatological and ice-sheet surface studies, based on these results, is the subject of several other papers (e.g. Dixon and others, 2004; Kaspari and others, 2004, 2005; Rick and Albert, 2004; Spikes and others, 2004; Schneider and others, 2005).

\section{SITE SELECTION, ICE CORING AND ANALYSIS}

West Antarctica has the specific advantage over East Antarctica as an ice-core drilling location that snow accumulation rates are generally high $(>8 \mathrm{~cm}$ ice equivalent; e.g. Vaughan and others, 1999). However, West Antarctic temperatures are high enough at lower elevations that problems associated with surface melting or diffusive changes of chemical properties may be a concern. Selection of coring sites took this into account and traverse routes were therefore restricted largely to the high-plateau portion of the WAIS. Some areas were avoided for purely logistical reasons, most importantly the presence of crevasses. Target coring depths were chosen with the goal of obtaining at least 200 years of climate history from each core, combined

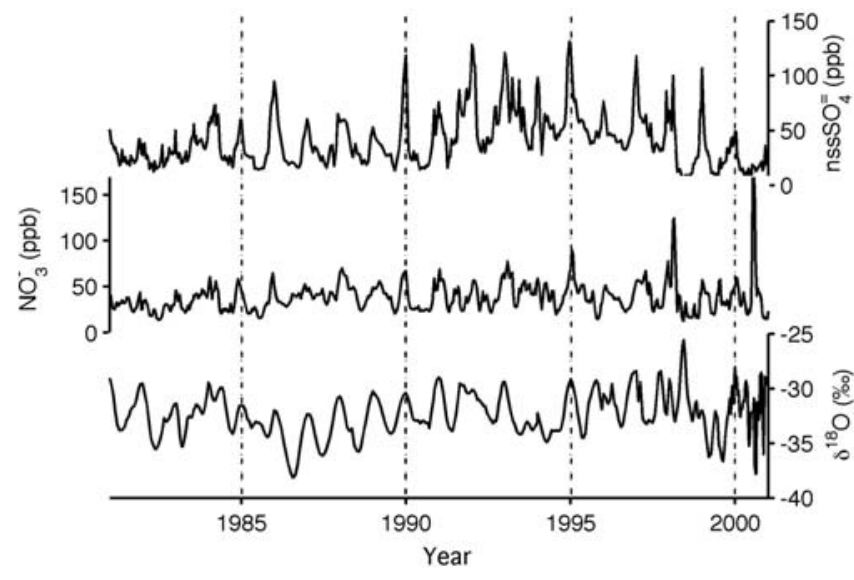

Fig. 2. Profiles of non-sea-salt sulfate $\left(\mathrm{nsSSO}_{4}{ }^{2-}\right)$, nitrate $\left(\mathrm{NO}_{3}{ }^{-}\right)$and oxygen isotope ratios $\left(\delta^{18} \mathrm{O}\right)$ in US ITASE core 2000-1, from 1981 to 2001. Note the distinct rise in sulfate levels beginning in 1991/92, due to the Pinatubo eruption. Dashed lines are for reference and show 1 January of selected years.

with efficiency of field operations. In practice, this meant that we obtained deeper cores $(>60 \mathrm{~m})$ only where it was deemed necessary due to the high accumulation rates, though at selected sites longer records were obtained. Core locations are shown in Figure 1. Elevations, latitudes and longitudes of the USITASE cores specifically discussed in this paper are given in the figure captions. Additional details on core depths and locations for all the US ITASE cores are archived at the US National Snow and Ice Data Center (www.nsidc.org).

Cores were retrieved using two different mechanical drilling systems. For the main ice core at each site, we used an Icefield Instruments Eclipse ${ }^{\mathrm{TM}}$ drill that obtains $1 \mathrm{~m}$ sections of $82 \mathrm{~mm}$ diameter cores. The drill was mounted on a sled and transported by snowmobile as a field-ready unit, saving drill set-up time. The Eclipse has the disadvantage of requiring that firn be excavated to allow space for the vertically swinging drill arm; thus the upper $1 \mathrm{~m}$ of snow cannot be sampled with the drill. In the first two field seasons we sampled the upper 1-2 $\mathrm{m}$ separately, after excavation for drill access, to obtain a continuous record up to the surface. In the third and fourth seasons we replaced firn-pit sampling with shallow coring, using a new system from Glacier Data ${ }^{\mathrm{TM}}$. The Glacier Data design is similar to that of the Eclipse but is considerably lighter and can drill directly from the surface; $50 \mathrm{~mm}$ diameter cores are obtained. We tested this drill to $40 \mathrm{~m}$ depth at Byrd Station and are confident that it can achieve much greater depths. Details on the drill designs are available from Icefield Instruments (www.icefield.yk.ca) and Glacier Data (www.glacierdata.com) respectively.

\section{Core loss}

In general, the $82 \mathrm{~mm}$ cores were packaged in the field and sampled later at the US National Ice Core Laboratory in Colorado; the $50 \mathrm{~mm}$ cores were either analyzed on-site or subsampled in the field and placed in cleaned sample containers, kept frozen until ready for analysis in the laboratory. All sampling was done by a team wearing Tyvek clean suits, masks and polypropylene gloves to prevent contamination. In the laboratory, established procedures were followed for clean chemical sampling using melter 


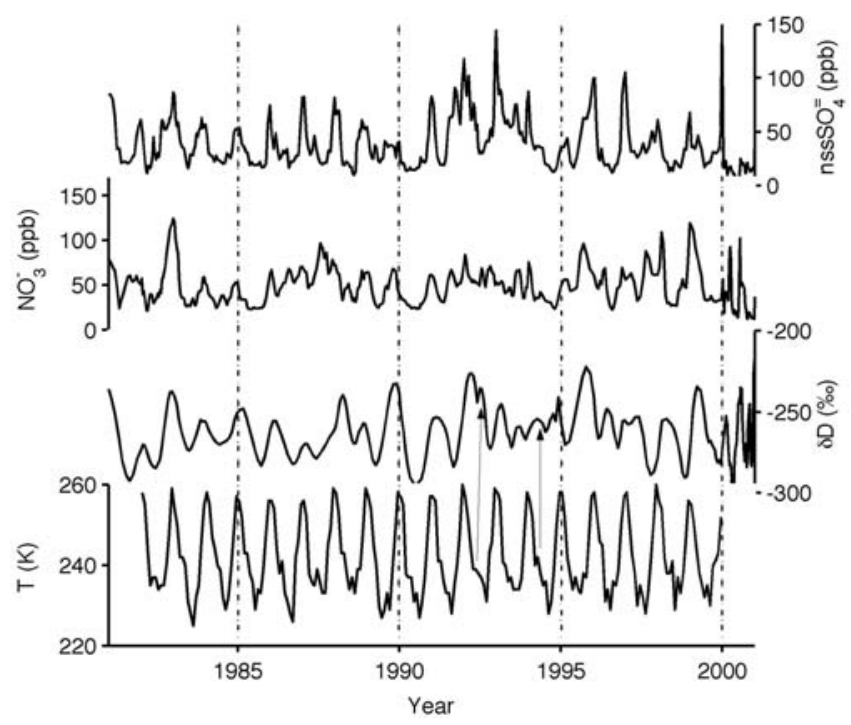

Fig. 3. Same as Figure 2, but for US ITASE core 2000-4, and also showing surface temperature from the Advanced Very High Resolution Radiometer (AVHRR) satellite. Arrows show suggested correlations between mid-winter warming events and mid-winter isotope (deuterium/hydrogen $=\delta \mathrm{D}$ ) anomalies.

heads designed to separately sample the outside and inside of the core. Concentrations of hydrogen peroxide, formaldehyde and selected major ions were measured by continuous flow analysis using the fluorescence or photometric detection methods (Röthlisberger and others, 2000) at the University of Arizona; stable-isotope concentrations $\left(\delta^{18} \mathrm{O}\right.$ and $\delta \mathrm{D})$ were analyzed by mass spectrometry using $\mathrm{CO}_{2}$ equilibration and $\mathrm{Cr}$ reduction at the University of Washington; all other geochemical measurements were conducted at the University of Maine using ion chromatography. Details of the sampling and measurement procedures used are given in Buck and others (1992) and Frey and others (in press).

\section{ESTABLISHMENT OF DEPTH-AGE RELATIONSHIPS FROM SEASONAL VARIATIONS}

Figures 2-6 show selected geochemical profiles from three sites (US ITASE 2000-1, 2000-4, and 2001-5) to illustrate the most important findings with respect to ice-core dating at USITASE sites in West Antarctica. Other core profiles are similar and support the conclusions derived from these examples. We refer to these figures in this and in subsequent sections of the paper.

For the relatively high-accumulation sites we selected, geochemical and physical properties of the USITASE cores show that there is excellent preservation of seasonal cycles in virtually all geochemical parameters and in grain-size variations that mark the transitions from summer to fall and winter to spring. This is a prerequisite for obtaining highquality timescales. We also found that agreement between results from the $82 \mathrm{~mm}$ ice cores, which generally start $\sim 1 \mathrm{~m}$ below the surface, and from the overlapping shallower snow pits and $50 \mathrm{~mm}$ cores, is excellent. Exceptions to the general rule of unambiguous seasonal indicators in the USITASE cores are:

1. at the lowest-elevation/warmest sites (1999-1 and 19992 ), diffusion of the more mobile species, notably hydrogen peroxide $\left(\mathrm{H}_{2} \mathrm{O}_{2}\right)$, water stable-isotope ratios

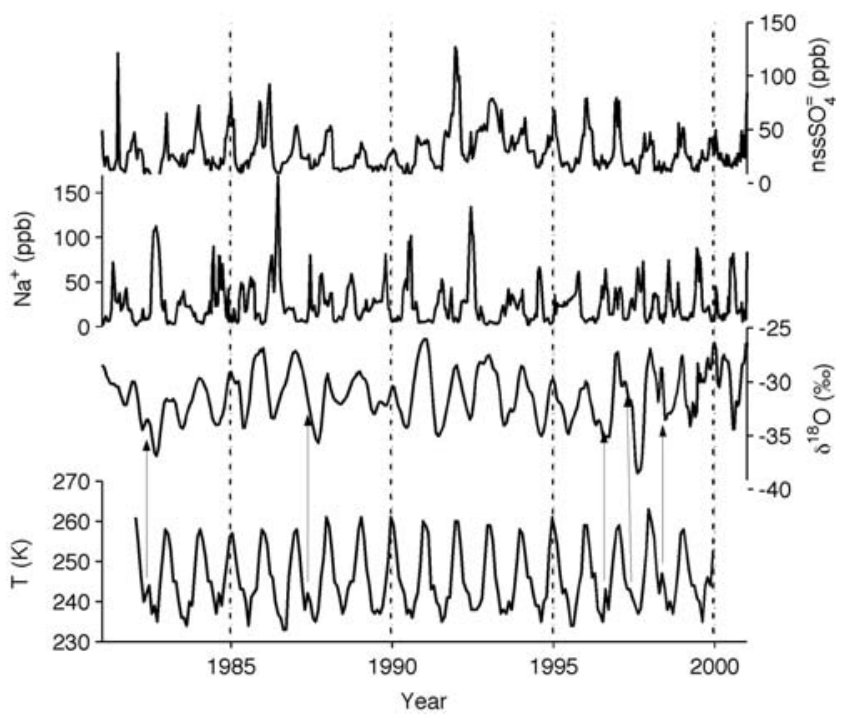

Fig. 4. Same as Figure 3, but for US ITASE core 2001-5, and showing sodium concentrations $\left(\mathrm{Na}^{+}\right)$in place of nitrate. Arrows show suggested correlations between mid-winter warming events and mid-winter oxygen isotope anomalies.

$\left(\delta^{18} \mathrm{O}, \delta \mathrm{D}\right)$ and nitrate $\left(\mathrm{NO}_{3}{ }^{-}\right)$, preclude the detection of seasonal cycles in these species beyond the upper $\sim 10 \mathrm{~m}$ of firn;

2. at most sites, we found that wind crusts in the physical stratigraphy were not reliably correlated with other indicators of annual snow accumulation; in general, we found more than one such layer in most years.

We established initial age vs depth relationships for the USITASE cores through the identification of seasonal peaks from all the major geochemical time series considered together $\left(\mathrm{SO}_{4}{ }^{2-}, \mathrm{Na}^{+}, \mathrm{Ca}^{2+}, \mathrm{Cl}^{-}, \mathrm{Mg}^{2+}, \mathrm{K}^{+}\right.$and $\left.\mathrm{NO}_{3}{ }^{-}\right)$, coupled with visual stratigraphy, but not including stableisotope ratios and hydrogen peroxide. In practice, we find that the least ambiguous seasonal variations are in the sulfate concentrations, and in particular the derived parameter $\mathrm{nssSO}_{4}{ }^{2-}$ (non-sea-salt sulfate, also referred to as 'excess sulfate', determined by applying a standard sea-water ratio of $30.61\left(\mathrm{Na}^{+}\right), 1.1\left(\mathrm{~K}^{+}\right), 3.69\left(\mathrm{Mg}^{2+}\right), 1.16\left(\mathrm{Ca}^{2+}\right), 55.04\left(\mathrm{Cl}^{-}\right)$ and $7.68\left(\mathrm{SO}_{4}{ }^{2-}\right)$ to the ion concentrations in each sample; see O'Brien and others (1995) and Dixon and others (2004) for details). Sulfate deposition in West Antarctica reflects both sea-salt and non-sea-salt sources, with a strong altitude dependence on their relative importance. At lower elevations, the biogenic-source $\mathrm{SO}_{4}{ }^{2-}$ fractions may overwhelm volcanic signals. This appears to be important at Siple Dome (elevation $600 \mathrm{~m}$ ), which when combined with the rapid diffusion of stable isotopes (Cuffey and Steig, 1998) and somewhat ambiguous visual stratigraphy, has made dating to the interannual level problematic at this site (Taylor and others, 2004b). In the case of the USITASE cores, there is a fairly small difference between the $\mathrm{SO}_{4}{ }^{2-}$ and $\mathrm{nsSO}_{4}{ }^{2-}$ data; however, using the latter has the advantage of narrowing the width of the seasonal maxima, and of accentuating anomalously large peaks that are identified with large, globally significant explosive volcanic events.

On the basis of two independent influences on seasonal sulfate concentrations, we assigned the $\mathrm{nsSSO}_{4}{ }^{2-}$ peaks to 


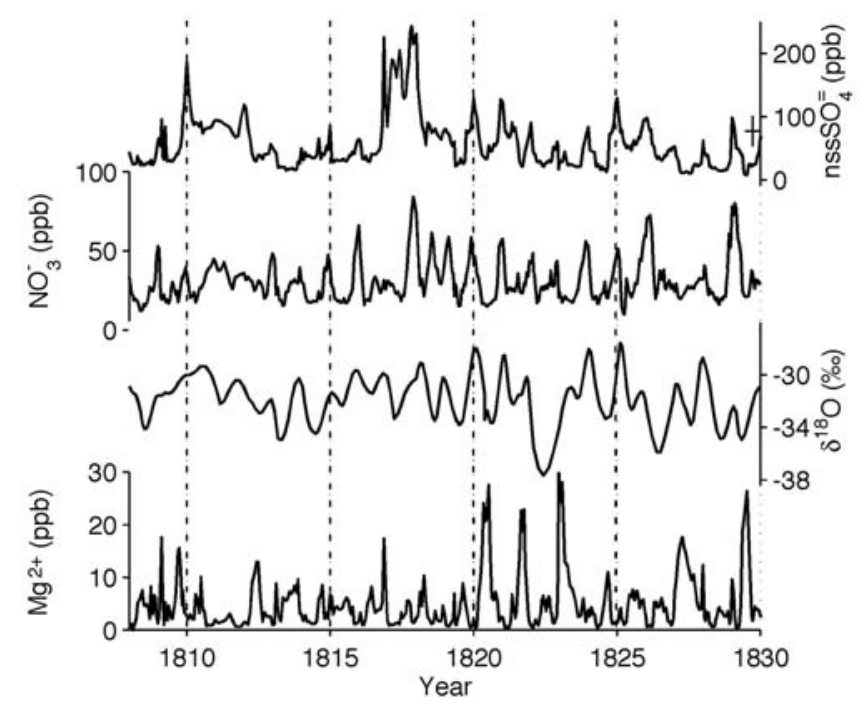

Fig. 5. Same as Figure 4, but showing the years 1808-30 in US ITASE core 2001-5, and showing $\mathrm{NO}_{3}{ }^{-}$in place of $\mathrm{Na}^{+}$, and showing magnesium concentrations $\left(\mathrm{Mg}^{2+}\right)$ in the bottom panel. Cross on right side of upper panel shows mean and standard deviation of $\mathrm{SO}_{4}{ }^{2-}$ concentrations measured in fresh snow during summer at core site 2001-6. Note significantly elevated sulfate levels in 1816-17, due to the Tambora eruption, and in 1810-11.

early summer (nominally 1 January) of each year (Figs 2-5). The primary source of $\mathrm{nsSSO}_{4}{ }^{2-}$ is the oxidation of various sulfur compounds beginning with dimethyl sulfide (DMS) which is produced by phytoplankton, with blooms generally beginning in December as sea-ice melt-induced surface water stratification becomes established, and peaking in early January (Arrigo and others, 1999; Kettle and others, 1999). The secondary source for $\mathrm{nssSO}_{4}{ }^{2-}$ is input from the upper troposphere and lower stratosphere, representing both volcanic inputs, and anthropogenic and additional biogenic sulfur from extrapolar regions (Delmas, 1982; Legrand and Mayewski, 1997). The peak input of this secondary source is also expected to occur in early austral summer, due to the spring-time break-up of the polar vortex. In addition to this a priori reasoning, numerous ice-core studies support the assignment of the $\mathrm{nssSO}_{4}{ }^{2-}$ peak to early summer (Whitlow and others, 1992; Wagenbach and others, 1998; Kreutz and Mayewski, 1999). Also, measurements of optical depth from the atmosphere at South Pole place the maxima precisely in early January (Bergin and others, 1998). Finally, we note that $\mathrm{nssSO}_{4}$ concentrations in fresh snow from a late December snowstorm in 2001, near site USITASE 2001-6, are indistinguishable from the typical ice-core $\mathrm{nssSO}_{4}$ maxima (Fig. 5).

\section{ACCURACY OF TIMESCALES}

Having established timescales for the cores that are based on seasonal variations alone, with $\mathrm{nssSO}_{4}{ }^{2-}$ providing the nominal assignment of calendar dates, i.e. time of year, we used several independent measures to validate the timescales. The validation procedures provide a means to estimate both the precision and accuracy of the timescales.

The identification of volcanic marker horizons provides a particularly important validation tool. In each of the US ITASE cores that have been analyzed for sulfate concentrations (US ITASE 1999-1, 2000-1, 2000-4, 2000-5, 2001-2,
2001-3, 2001-5) and in several additional West Antarctic cores, Dixon and others (2004) identified elevated $\mathrm{nssSO}_{4}{ }^{2-}$ levels at times consistent with the known dates of eruption of the following volcanoes (dates given in parentheses): Tambora, Indonesia (1815); Cosiguina, Nicaragua (1835); Krakatau, Indonesia (1883); Agung, Indonesia (1963); Pinatubo, Philippines, and Cerro Hudson, Chile (1991). An 'unknown' event, which has an established age of 1808/09 from Greenland ice cores and other evidence (Zielinski and others, 1994; Chenoweth, 2001), was also identified. Specifically, elevated levels of $\mathrm{nssSO}_{4}{ }^{2-}$ begin in 1810 , 1816, 1837, 1885, 1964 and 1992. These ages, from the independent layer counting, are consistently 1-2 years after the eruption date of the volcanoes assigned to them, consistent with the typical stratospheric transport time across the circumpolar vortex. For the most recent volcanoes, we know from satellite observations that the stratospheric $\mathrm{SO}_{4}{ }^{2-}$ clouds from Cerro Hudson and Pinatubo were centered over the South Pole in September and November 1991 (Cacciani and others, 1993; Saxena and others, 1995). Because the seasonal cycle in $\mathrm{SO}_{4}{ }^{2-}$ begins to rise in September, it is difficult to demonstrate that the volcanic signal is registered precisely at the expected time. However, the background levels clearly begin to rise no earlier than 1991 and no later than 1992 in all cores (Figs 2-4), and the most prominent summer peak in all of the cores, after the 1964 peak attributed to Agung, occurs in January 1992.

On the basis of the seasonal ion-chemistry data and the volcanic marker horizons, a conservative estimate for the absolute dating accuracy for the USITASE cores is $< \pm 2$ years. Strictly, this applies only at the times of the identified horizons. A concern that arises in assigning this value to the entire length of the cores is the possibility that, while the length of time between different volcanic horizons may be correct, there may be some timescale variation within these intervals that is greater than 1 year, particularly for the longer interval 1886-1963 when no volcanic horizons were identified. Indeed, in examining the $\delta^{18} \mathrm{O}$ record from site 2001-5, we noted one year (1893) in which there appeared to be a 'missing' $\delta^{18} \mathrm{O}$ annual cycle. Subsequent review of the nssSO ${ }_{4}{ }^{2-}$ profile also showed a weak $\mathrm{nsSO}_{4}{ }^{2-}$ peak at this time, suggesting that this year may have been misidentified as a summer peak. No such differences were observed in the other cores analyzed. Based on this comparison, we consider the overall, absolute dating accuracy to be conservatively \pm 2 years overall, and much better than \pm 1 year in the most recent (last $\sim 20$ years) parts of the USITASE cores.

We can further demonstrate that the relative dating accuracy is in general no worse than 1 year. In particular, this higher level of accuracy applies for all the cores at those depths at which volcanic horizons (or total beta measurements that reveal known atomic bomb test events) have been identified, since all of these horizons occur in the same year in all of the cores analyzed (Dixon and others, 2004). For two of the cores, we can further demonstrate a relative dating accuracy of \pm 1 year throughout the entire length of the records. Spikes and others (2004) showed, using shallow radar stratigraphy, that it was possible to unambiguously trace lines from the 2000-4 site to the 2000-5 site and to obtain identical ages \pm 1 year at each. Arcone and others (2005) have also traced layers between sites 2000-4 and 2000-2, and place the 1991 summer layer at $10.1 \mathrm{~m}$ depth at 2000-2. While core 2000-2 remains to be processed for 


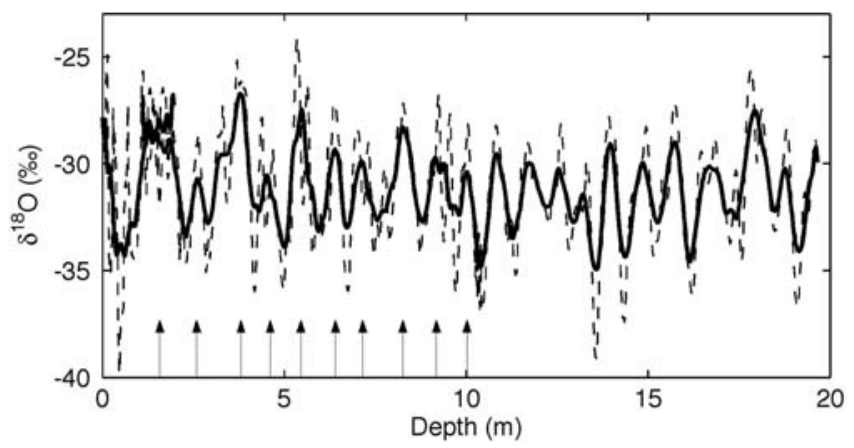

Fig. 6. Oxygen isotope $\left(\delta^{18} \mathrm{O}\right)$ record from US ITASE core 2000-2. Dashed line is measured data; bold line shows 19-point smoothed data. Arrows show inferred annual summer peaks between the surface (2001) and the depth of the radar reflector, independently attributed to the year 1991 from correlation with US ITASE core 2000-4.

most geochemical measurements, from the stable-isotope profile (Fig. 6) we obtain $10.2 \mathrm{~m}$ for summer 1991, amounting to a difference of $\sim 1$ month at this highaccumulation site (estimated $46 \mathrm{~g} \mathrm{~cm}^{-2} \mathrm{a}^{-1}$ mean for the past decade). The hydrogen peroxide record also indicates a depth of $10.2 \mathrm{~m}$ for late spring 1990 (Frey and others, in press).

Additional information from the stable-isotope and hydrogen peroxide concentrations further supports the estimated \pm 1 year accuracy. Seasonal $\delta^{18} \mathrm{O}, \delta \mathrm{D}$ and $\mathrm{H}_{2} \mathrm{O}_{2}$ cycles in these cores, which were not used in the original layer counting, provide an independent check on the assumption that the $\mathrm{nssSO}_{4}{ }^{2-}$ variations are seasonal. For most cores, the $\delta^{18} \mathrm{O}$ cycles are unambiguously seasonal through at least AD 1900, except for cores 1999-1 and 1999-2 where rapid isotope diffusion eliminates the seasonal variations at much shallower depths. In some cores the seasonal variations are detectable through the entire length (e.g. sites 2001-5 (Fig. 5) and 2002-4 (Jacobel and others, 2005)). For the most recent 20 years, the stableisotope ratios provide an especially robust indicator of accuracy, because of the strong link between stable-isotope ratios and temperature. Schneider and others (2005) show that the correlation between climatological monthly mean stable-isotope values in these cores and local monthly temperature anomalies from AVHRR satellite observations is $r=0.98$. (The 'climatological monthly mean' is the mean of all Januarys, all Februarys, etc. for 1982-99.) There is a distinctive mid-winter warming period that appears at some sites in some years in the temperature records. We find that there are elevated isotope values at the corresponding sites in the correct years (Figs 3 and 4). Shuman and others (1995) found a similar correspondence in Greenland ice cores. We cannot demonstrate this for all the cores; in USITASE core 2000-1, for example, diffusion has eliminated sub-seasonal variations. Importantly, though, while there are some years in which the isotope anomalies do not appear, there are no years in which the mid-winter isotope values are elevated without a corresponding mid-winter warming seen in the temperature records. This is particularly clear at the highestaccumulation site, in core 2001-5 (Fig. 4). These results indicate that the correct years have been identified with no uncertainty for at least the last 20 years, i.e. the length of the satellite records.

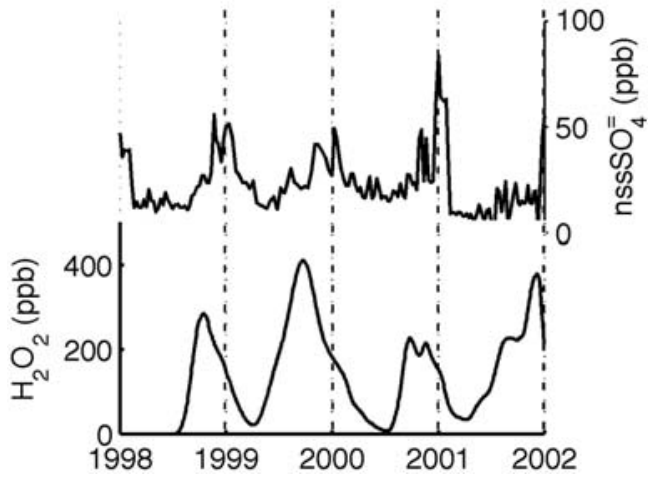

Fig. 7. Comparison of $\mathrm{nssSO}_{4}{ }^{2-}$ and $\mathrm{H}_{2} \mathrm{O}_{2}$ concentrations in US ITASE core 2001-5, between 1998 and 2002.

\section{PRECISION OF TIMESCALES}

We now consider the dating precision of the US ITASE cores. By precision, in this context, we mean the uncertainty in correct assignment of calendar months for individual years in the records. The annual-layer counts are defined in terms of peak-to-peak intervals between nominally 'summer' values of geochemical measurements. In all cases, we used simple linear interpolation to define the timescale between these nominal 1 January values. The precision of the timescales thus depends on the precision of the assumptions (1) that the $\mathrm{nsSO}_{4}{ }^{2-}$ peaks actually coincide with 1 January and (2) that net snow accumulation is uniform throughout the year.

While there is no direct way to test these assumptions in the past, we noted above that there is independent evidence that the $\mathrm{nsSO}_{4}{ }^{2-}$ peaks in early January (Bergin and others, 1998), and that this timing reflects a combination of sea-ice melt and the break-up of the polar vortex. Analyses of sea surface DMS concentrations (Kettle and others, 1999), seaice variations (personal communication from C. Bitz, 2004), and stratospheric temperatures from US National Centers for Environmental Prediction (NCEP)/US National Center for Atmospheric Research (NCAR) re-analysis data (Waugh and others, 1999) indicate that all vary by $<1$ month, which would suggest that the maximum in $\mathrm{nsSSO}_{4}{ }^{2-}$ peak also varies by about this amount except during volcanic events. We also have some direct evidence that it is reasonable to attribute the midpoint in seasonal $\mathrm{nssSO}_{4}{ }^{2-}$ to 'winter' (nominally 1 July by linear interpolation). As shown in Figures 4 and 7, maxima in sodium $\left(\mathrm{Na}^{+}\right)$and minima in hydrogen peroxide $\left(\mathrm{H}_{2} \mathrm{O}_{2}\right)$ and stable isotopes all occur within 1-2 months of the nominal midpoint of the year, consistent with previous observations suggesting these are all winter signatures. As noted above, the occurrence of some mid-winter warming events in the stable-isotope records further indicates correct identification of winter layers to within $\sim 1$ month (Figs 3 and 4). The $\mathrm{H}_{2} \mathrm{O}_{2}$ data provide perhaps the most robust evidence for the timing of mid-winter, since the predominant source of atmospheric $\mathrm{H}_{2} \mathrm{O}_{2}$ is of photochemical origin, limiting production to the sunlit season. The only existing set of all-year-round measurements of $\mathrm{H}_{2} \mathrm{O}_{2}$ in the Antarctic troposphere stems from a coastal site and shows a distinct seasonal cycle, with a minimum around the winter solstice (Riedel and others, 2000). Year-round snow sample studies at the South Pole provide evidence that the same annual cycle is recorded in the surface snow and preserved at depth as a function of 

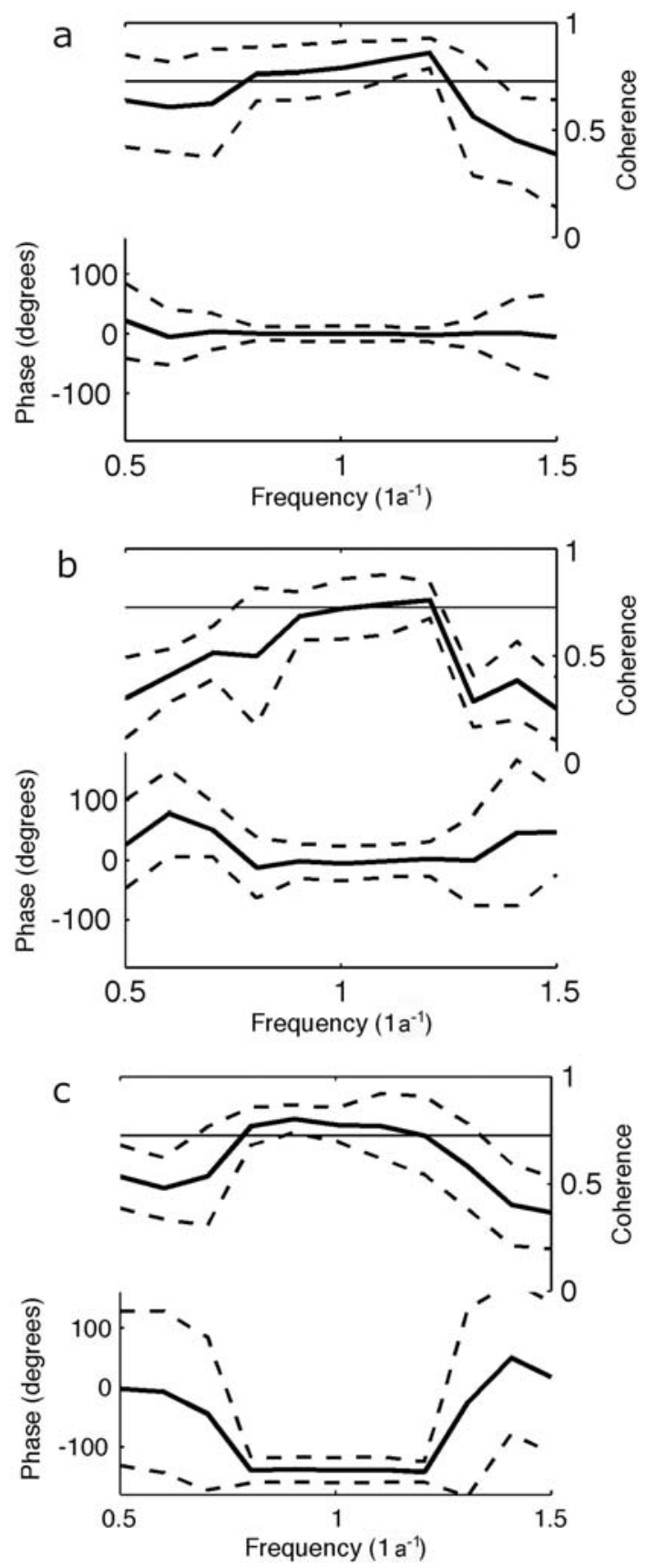

Fig. 8. Coherence and phase for non-sea-salt sulfate $\left(\mathrm{SO}_{4}{ }^{2-}\right)$ compared with (a) $\mathrm{NO}_{3}^{-}$in US ITASE core 2001-5; (b) $\delta^{18} \mathrm{O}$ in core 2000-5; and (c) $\mathrm{Na}^{+}$in core 2000-4. The bandwidth is $\sim 0.1$ months. Bold lines show mean value; dashed lines are one standard deviation based on 10 year increments. Horizontal solid line in each upper panel is the $95 \%$ confidence limit for coherence.

accumulation rate and temperature (McConnell and others, 1998). Hydrogen peroxide shows preservation of the seasonal signature at all core sites with more than approximately $30 \mathrm{~g} \mathrm{~cm}^{-2} \mathrm{a}^{-1}$ of annual accumulation down to depths $>60 \mathrm{~m}$ (Frey and others, in press). Unfortunately, strong diffusional loss to the atmosphere and redistribution within the firn preclude a precise attribution of mid-winter at low-accumulation sites $\left(<15 \mathrm{~g} \mathrm{~cm}^{-2} \mathrm{a}^{-1}\right)$ beyond the upper $\sim 10 \mathrm{~m}$ of the firn (Frey and others, in press).

On the basis of the above discussion, we suggest that a precision of \pm 1 month is a conservative estimate for the US ITASE cores, at least for the most recent years where we have independent calibration from the satellite-based temperature data. To verify that this stated precision is applicable to the full length of the records, we quantitatively examined the timing of $\mathrm{nssSO}_{4}{ }^{2-}$ relative to other seasonal markers. To do this, we determined the variability in the coherence and phase of nssSO ${ }_{4}{ }^{2-} \mathrm{vs} \mathrm{NO}_{3}{ }^{-}, \mathrm{Na}^{+}$and stable isotopes in each of the cores. We calculated the Thompson multi-taper (Thomson, 1982; Percival and Walden, 1993) phase and coherence spectra using three tapers over successive 10 year intervals from AD 1900 to 2000 to determine the mean and standard deviation of the phase. In all cases, greatest coherence is (as expected) at the annual cycle (i.e. frequency $=1 \mathrm{a}^{-1}$ ), and the phase at this frequency varies by $<1$ month. There is no temporal trend in either phase or coherence (though we restricted our analysis to the interval 1900-2000 because of diffusion of the seasonal $\delta^{18} \mathrm{O}$ variations). As illustrated in Figure 8a, $\mathrm{NO}_{3}{ }^{-}$is in phase $\left(0.0 \pm 0.4\right.$ months) with $\mathrm{nssSO}_{4}{ }^{2-}$, consistent with the evidence that, like $\mathrm{nssO}_{4}{ }^{2-}$, its variability is influenced by input from the upper troposphere/lower stratosphere (Mayewski and Legrand, 1990; Mulvaney and Wolff, 1993). Stable isotopes (Fig. 8b) are closely in phase with $\mathrm{nssSO}_{4}{ }^{2-}$ as well, with a slight lead of 0.1 months ( \pm 0.9 month), consistent with the timing of warmest temperatures and the high seasonal isotope/temperature correlation (Schneider and others, 2005). Finally, $\mathrm{Na}^{+}$ (Fig. 8c) leads nssSO ${ }_{4}{ }^{2-}$ by $\sim 5 \pm 0.7$ months, consistent with other evidence that $\mathrm{Na}^{+}$peaks in late winter (Bergin and others, 1998; Kreutz and others 2000b). Given that advection to the ice sheet of sea-salt aerosols by both summer and winter storms can lead to enhanced $\mathrm{Na}^{+}$ concentrations, as expressed in relatively noisy $\mathrm{Na}^{+}$records with multiple peaks in a given year (Fig. 4), the consistency of phase is remarkable, and further attests to the consistency in the seasonal timing of the $\mathrm{nssSO}_{4}{ }^{2-}$ peaks. This suggests that the identification of 'winter' in our records (nominally 1 July) is also precise to \pm 1 month. This in turn implies that snowfall throughout the year in West Antarctica is reasonably uniform: there is apparently insufficient variability in the seasonal timing of snowfall to influence the phase relationships by more than 1 month. Preservation of all annual layers further indicates that wind erosion or sublimation is insufficient in magnitude to remove annual snow accumulation. Both of these inferences are consistent with the precipitation modeling analyses of Bromwich and others (2004), which indicate a seasonal variation in snowfall amounts in West Antarctica of $<25 \%$ and sublimation over precipitation ratios of $<15 \%$.

\section{DISCUSSION}

Recent work using paleoclimate proxy data has highlighted the importance of obtaining multiple, well-dated records at annual or better resolution, that can be used in calibration against the spatially comprehensive, but temporally very short, instrumental record of climate. Many analyses have emphasized tree ring records, primarily because the dating accuracy is excellent, and also because such records are available from nearly all continents and can therefore provide a representative sampling of climate variability (e.g. Mann and others, 1998; Jones and Widmann, 2003). As a general rule, available ice-core records have been too spatially sparse, and insufficiently resolved to contribute significantly to quantitative paleoclimate syntheses (Mann 
and Jones, 2003), except where the longest timescales are concerned. Yet the polar regions, and Antarctica in particular, represent a large area that is inaccessible to such methods unless ice cores are used. An additional hindrance is that the instrumental record in Antarctica is particularly sparse and short, essentially limited to the last $\sim 40$ years.

One of the major goals of the overall ITASE program is to document Antarctic climate variability in the recent past (the last 200-2000 years) by obtaining highly resolved ice-core records distributed across the Antarctic ice sheet. Obtaining both high resolution and a high level of accuracy and precision is critical if we are to use multiple ice cores together as stacked records to reduce noise, or in multivariate regression models that are calibrated directly against the instrumental climate record (e.g. Schneider and others, 2005). The accuracy and precision obtained for the US ITASE cores recovered and analyzed from West Antarctica represent a significant contribution toward these efforts.

Importantly, for the period of overlap with the instrumental data ( $\sim 40$ years, and only $\sim 20$ years for satellite data), the absolute accuracy is demonstrably better than 1 year, and precision is well below the length of a season, allowing for calibration against both annually averaged and seasonal indicators of climate variability from the instrumental record. For longer-term records, the estimated relative accuracy of \pm 1 year is very promising, as any systematic errors would affect all the cores together and therefore be negligible for these cores taken as a group. We further emphasize that we consider our estimates of absolute accuracy $(< \pm 2$ years) to be quite conservative, given the relative accuracy of $< \pm 1$ year from the radar analyses. In section 3, we raised the point that we cannot rule out systematic biases in the cores between the stratigraphic tie points provided by the volcanic horizons. However, we suggest that it is in fact quite unlikely that the same number of years have been misidentified in multiple ice cores. That the ice-core-based age of the Tambora eruption is identical in all of the records is suggestive of an absolute accuracy of $< \pm 1$ year. It is further notable that, in general, dating accuracy in layer-counted ice cores is expected to decrease with depth (age), since errors in layer counting will be cumulative. In the case of the US ITASE cores, however, the accuracy should be approximately uniform in distribution, because there is a roughly even distribution of well-dated volcanic layers throughout the cores.

Accurate and precise dating of paleoclimate proxy records is a critical step in using such records to extend our knowledge of climate and environmental change prior to the time period covered by the instrumental record. Our analyses suggest that the use of multiple Antarctic ice cores for quantitative investigation of climate variability on timescales significantly shorter than decadal is feasible with existing data. Complete spatial coverage of the Antarctic continent will be important. The spatial coverage of welldated ice cores from West Antarctica, plus published data from East Antarctica, appears to be sufficient to reconstruct Antarctic mean temperature over the last $\sim 100-200$ years (Schneider and others, 2005), and may be adequate for reconstruction of interannual variations in the 'Southern Annular Mode' (Thompson and Wallace, 2000), but may be insufficient to reconstruct higher-order patterns of variability, such as the Pacific South America (Schneider and others, 2005) or 'Antarctic Dipole' (Yuan and Martinson, 2001) patterns in temperature, sea-ice and geopotential height anomalies. It will therefore be important to combine records from the USITASE cores with those from other ITASE projects, and with existing highly resolved cores such as Law Dome in East Antarctica (Masson-Delmotte and others, 2003) and the Dyer Plateau on the Peninsula (Thompson and others, 1994). Care must be taken to ensure that consistent standards of accuracy and precision are used in all datasets.

\section{ACKNOWLEDGEMENTS}

We gratefully acknowledge the support of the US Antarctic Research Program, the New York Air National Guard 109th Airborne Division, the staff of Raytheon Polar Services and A. Zielinski at the University of Maine for help in, and getting to, the field. The first author was supported by grant OPP 0196105 from the US National Science Foundation. Suggestions by R. Mulvaney and two anonymous reviewers led to improvements to the manuscript.

\section{REFERENCES}

Arcone, S.A., V.B. Spikes and G.S. Hamilton. 2005. Phase structure of radar stratigraphic horizons within Antarctic firn. Ann. Glaciol., 41 (see paper in this volume).

Arrigo, K. and 6 others. 1999. Phytoplankton community structure and the drawdown of nutrients and $\mathrm{CO}_{2}$ in the Southern Ocean. Science, 283(5400), 365-367.

Bergin, M.H., E.A. Meyerson, J.E. Dibb and P.A. Mayewski. 1998. Relationship between continuous aerosol measurements and firn core chemistry over a 10-year period at the South Pole. Geophys. Res. Lett., 25(8), 1189-1192.

Bromwich, D.H., Z. Guo, L. Bai and Q. Chen. 2004. Modelled Antarctic precipitation. Part I: spatial and temporal variability. J. Climate, 17(3), 427-447.

Buck, C.F., P.A. Mayewski, M.J. Spencer, S. Whitlow, M.S. Twickler and D. Barrett. 1992. Determination of major ions in snow and ice cores by ion chromatography. J. Chromatogr., 594(1-2), 225-228.

Cacciani, M., P. di Girolamo, A. di Sarra, G. Fiocco and D. Fua. 1993. Volcanic aerosol layers observed by lidar at South Pole, September 1991-June 1992. Geophys. Res. Lett., 20(9), 807-810.

Chenoweth, M. 2001. Two major volcanic cooling episodes derived from global marine air temperature, AD 1807-1827. Geophys. Res. Lett., 28(15), 2963-2966.

Cuffey, K.M. and E.J. Steig. 1998. Isotopic diffusion in polar firn: implications for interpretation of seasonal climate parameters in ice-core records, with emphasis on central Greenland. J. Glaciol., 44(147), 273-284.

Delmas, R. 1982. Antarctic sulphate budget. Nature, 299(5885), $677-678$.

Dixon, D., P.A. Mayewski, S. Kaspari, S. Sneed and M. Handley. 2004. A 200-year sub-annual record of sulfate in West Antarctica from 16 ice cores. Ann. Glaciol., 39, 545-556.

Frey, M.M., R.C. Bales and J.R. McConnell. In press. Climate sensitivity of the century-scale hydrogen peroxide $\left(\mathrm{H}_{2} \mathrm{O}_{2}\right)$ record preserved in 23 ice cores from West Antarctica. J. Geophys. Res.

Jacobel, R., B.C. Welch, E. Steig and D. Schneider. 2005. Glaciological and climatic significance of Hercules Dome, Antarctica - an optimal site for deep ice core drilling. J. Geophys. Res., 110(F1), F01015. (10.1029/2004JF000188.)

Johnsen, S.J., W. Dansgaard, H.B. Clausen and C.C. Langway, Jr. 1972. Oxygen isotope profiles through the Antarctic and Greenland ice sheets. Nature, 235(5339), 429-434.

Jones, J.M. and M. Widmann. 2003. Instrument- and tree-ringbased estimates of the Antarctic oscillation. J. Climate, 16(21), $3511-3524$ 
Jouzel, J. and 12 others. 2001. A new 27 ky high resolution East Antarctic climate record. Geophys. Res. Lett., 28(16), 3199-3202.

Kaspari, S. and 6 others. 2004. Climate variability in West Antarctica derived from annual accumulation rate records from ITASE firn/ice cores. Ann. Glaciol., 39, 585-594

Kaspari, S., P.A. Mayewski, D.A. Dixon, S.B. Sneed and M.J. Handley. 2005. Sources and transport pathways of marine aerosol species into West Antarctica. Ann. Glaciol., 41 (see paper in this volume).

Kettle, A.J. and 31 others. 1999. A global database of sea surface dimethyl sulfide (DMS) measurements and a procedure to predict sea surface DMS as a function of latitude, longitude, and month. Global Biogeochemical Cycles, 13(2), 399-444.

Kreutz, K.J. and P.A. Mayewski. 1999. Spatial variability of Antarctic surface snow glaciochemistry: implications for paleoatmospheric circulation reconstructions. Antarct. Sci., 11(1), 105-118.

Kreutz, K.J., P.A. Mayewski, L.D. Meeker, M.S. Twickler and S.I. Whitlow. 2000a. The effect of spatial and temporal accumulation rate variability in West Antarctica on soluble ion deposition. Geophys. Res. Lett., 27(16), 2517-2520.

Kreutz, K.J., P.A. Mayewski, I.I. Pittalwala, L.D. Meeker, M.S. Twickler and S.I. Whitlow. 2000b. Sea level pressure variability in the Amundsen Sea region inferred from a West Antarctic glaciochemical record. J. Geophys. Res., 105(D3), 4047-4059.

Legrand, M. and P. Mayewski. 1997. Glaciochemistry of polar ice cores: a review. Rev. Geophys., 35(3), 219-243.

Mann, M.E. and P.D. Jones. 2003. Global surface temperatures over the past two millennia. Geophys. Res. Lett., 30(15), 1820. (10.1029/2003GL017814.)

Mann, M.E., R.S. Bradley and M.K. Hughes. 1998. Global-scale temperature patterns and climate forcing over the past six centuries. Nature, 392(6678), 779-787.

Masson-Delmotte, V. and 6 others. 2003. Recent southern Indian Ocean climate variability inferred from a Law Dome ice core. Climate Dyn., 21(2), 153-166. (10.1007/s00382-003-0321-9.)

Mayewski, P.A. and I.D. Goodwin. 1996. International TransAntarctic Scientific Expedition (ITASE) '200 years of past Antarctic climate and environmental change'. Science and implementation plan, 1996. PAGES Workshop Report 97-1.

Mayewski, P.A. and M. Legrand. 1990. Recent increase in nitrate concentration of Antarctic snow. Nature, 346(6281), 258-260.

McConnell, J.R., R.C. Bales, R.W. Stewart, A.M. Thompson, M.R. Albert and R. Ramos. 1998. Physically based modeling of atmosphere-to-snow-to-firn transfer of $\mathrm{H}_{2} \mathrm{O}_{2}$ at South Pole. J. Geophys. Res., 103(D9), 10,561-10,570.

Mosley-Thompson, E., L.G. Thompson, P.M. Grootes and N. Gundestrup. 1990. Little Ice Age (neoglacial) paleoenvironmental conditions at Siple Station, Antarctica. Ann. Glaciol., 14, 199-204.

Mulvaney, R. and E.W. Wolff. 1993. Evidence for winter/spring denitrification of the stratosphere in the nitrate record of Antarctic firn cores. J. Geophys. Res., 98(D3), 5213-5220.

O'Brien, S.R., P.A. Mayewski, L.D. Meeker, D.A. Meese, M.S. Twickler and S.I. Whitlow. 1995. Complexity of Holocene climate as reconstructed from a Greenland ice core. Science, 270(5244), 1962-1964.

Percival, D.B. and A.T. Walden. 1993. Spectral analysis for physical applications: multitaper and conventional univariate techniques. Cambridge, Cambridge University Press.

Rick, U.K. and M.R. Albert. 2004. Microstructure and permeability in the near-surface firn near a potential U.S. deep drilling site in West Antarctica. Ann. Glaciol., 39, 62-66.
Riedel, K., R. Weller, O. Schrems and G. König-Langlo. 2000. Variability of hydrogen peroxide and methylhydroperoxide in the Antarctic troposphere. Atmos. Environ., 34, 5225-5234.

Röthlisberger, R. and 6 others. 2000. Technique for continuous high-resolution analysis of trace substances in firn and ice cores. Environ. Sci. Technol., 34(2), 338-342.

Saxena, V.K., J. Anderson and N.H. Lin. 1995. Changes in Antarctic stratospheric aerosol characteristics due to volcanic eruptions as monitored by the Stratospheric Aerosol and Gas Experiment II satellite. J. Geophys. Res., 100(D8), 16,735$16,751$.

Schneider, D.P. and E.J. Steig. 2002. Spatial and temporal variability of Antarctic ice sheet microwave brightness temperatures. Geophys. Res. Lett., 29(20), 1964. (10.1029/2002GL015490.)

Schneider, D.P., E.J. Steig and J.C. Comiso. 2004. Recent climate variability in Antarctica from satellite-derived temperature data. J. Climate, 17(7), 1569-1583.

Schneider, D.P., E.J. Steig and T. van Ommen. 2005. Highresolution ice-core stable-isotopic records from Antarctica: towards interannual climate reconstruction. Ann. Glaciol., 41 (see paper in this volume).

Shuman, C.A., R.B. Alley, S. Anandakrishnan and C.R. Stearns. 1995. An empirical technique for estimating near-surface air temperature trends in central Greenland from SSM/I brightness temperatures. Remote Sens. Environ., 51(2), 245-252.

Spikes, V.B., G.S. Hamilton, S.A. Arcone, S. Kaspari and P. Mayewski. 2004. Variability in accumulation rates from GPR profiling on the West Antarctic plateau. Ann. Glaciol., 39, 238-244.

Taylor, K.C. and 13 others. 2004a. Abrupt late glacial climate change in the Pacific sector of Antarctica. Quat. Sci. Rev., 23(1), 7-15.

Taylor, K.C. and 13 others. 2004b. Dating the Siple Dome (Antarctica) ice core by manual and computer interpretation of annual layering. J. Glaciol., 50(170), 453-461.

Thompson, D.W.J. and J.M. Wallace. 2000. Annular modes in the extratropical circulation. Part I: Month-to-month variability. J. Climate, 13(5), 1000-1016.

Thompson, L.G. and 7 others. 1994. Climate since AD 1510 on Dyer Plateau, Antarctic Peninsula: evidence for recent climate change. Ann. Glaciol., 20, 420-426.

Thomson, D.J. 1982. Spectrum estimation and harmonic analysis. Proc. IEEE, 70, 1055-1096.

Vaughan, D.G., J.L. Bamber, M.B. Giovinetto, J. Russell and A.P.R. Cooper. 1999. Reassessment of net surface mass balance in Antarctica. J. Climate, 12(4), 933-946.

Wagenbach, D. and 7 others. 1998. Sea-salt aerosol in coastal Antarctic regions. J. Geophys. Res., 103(D9), 10,961-10,974.

Watanabe, O., J. Jouzel, S. Johnsen, F. Parrenin, H. Shoji and N. Yoshida. 2003. Homogeneous climate variability across East Antarctica over the past three glacial cycles. Nature, 422(2805), 509-512.

Waugh, D.W., W.J. Randel, S. Pawson, P.A. Newman and E.R. Nash. 1999. Persistence of the lower stratospheric polar vortices. J. Geophys. Res., 104(D22), 27,191-27,201.

Whitlow, S., P.A. Mayewski and J.E. Dibb. 1992. A comparison of major chemical species seasonal concentration and accumulation at the South Pole and Summit, Greenland. Atmos. Environ., 26A(11), 2045-2054.

Yuan, X. and D.G. Martinson. 2001. The Antarctic dipole and its predictability. Geophys. Res. Lett., 28(18), 3609-3612.

Zielinski, G.A. and 8 others. 1994. Record of volcanism since 7000 B.C. from the GISP2 Greenland ice core and implications for the volcano-climate system. Science, 264(5161), 948-952. 